\title{
Surface fault ruptures associated with the 14 April foreshock (Mj 6.5) of the 2016 Kumamoto earthquake sequence, southwest Japan
}

\author{
Nobuhiko Sugito $^{1 *} \mathbb{D}$, Hideaki Goto ${ }^{2}$, Yasuhiro Kumahara ${ }^{3}$, Hiroyuki Tsutsumi ${ }^{4}$, Takashi Nakata ${ }^{5}$, \\ Kyoko Kagohara ${ }^{6}$, Nobuhisa Matsuta ${ }^{7}$ and Haruka Yoshida ${ }^{8}$
}

\begin{abstract}
The 2016 Kumamoto earthquake sequence was a rare event worldwide in that the surface ruptures associated with the largest foreshock (Mj 6.5) of 21:26 (JST), 14 April ruptured again during the mainshock (Mj 7.3) of 01:25 (JST), 16 April. The 14 April Mj 6.5 earthquake produced 6-km-long surface ruptures along the central portion of the FutagawaHinagu fault zone (FHFZ). The mainshock produced 31-km-long surface ruptures along the central to northeastern part of the FHFZ. Field observations and eyewitness accounts documented that the offsets of the ruptures associated with the 14 April foreshock became larger after the 16 April mainshock, suggesting that the same portion of the fault ruptured to the surface twice in the Kumamoto earthquake sequence. The $6-\mathrm{km}$-long surface ruptures associated with the largest foreshock are located near a geometric bend of the FHFZ characterized by $\sim 50^{\circ}$ change in strike. The epicenter of the mainshock is also located near the bend. These observations imply that the Kumamoto earthquake sequence was initiated due to a stress concentration on the bend of the FHFZ, and the mainshock was initiated approximately at the same place about $28 \mathrm{~h}$ after the largest foreshock. This foreshock/mainshock sequence of the Kumamoto earthquake is not successive events on the adjacent different fault zones, because the 6-km-long surface ruptures of the largest foreshock are part of the 31-km-long surface ruptures of the mainshock.
\end{abstract}

Keywords: 2016 Kumamoto earthquake sequence, Largest foreshock, Mainshock, Futagawa-Hinagu fault zone, Geometric bend, Surface ruptures

\section{Introduction}

A destructive earthquake of $\mathrm{Mj} 7.3(\mathrm{Mw} 7.0)$ occurred in the Kumamoto area, southwest Japan, at 01:25 (JST), April 16, 2016, which corresponds to the mainshock of the Kumamoto earthquake sequence (Fig. 1a, b) (Japan Meteorological Agency (JMA) 2016a, b). The mainshock was caused by the movement of the central to northeastern part of the dextral Futagawa-Hinagu fault zone (FHFZ) (Watanabe et al. 1979; Research Group for Active Faults of Japan RGAFJ 1991; Ikeda et al. 2001; Nakata et al. 2001; Nakata and Imaizumi 2002) and produced

\footnotetext{
*Correspondence: nsugito@hosei.ac.jp

1 Faculty of Sustainability Studies, Hosei University, Tokyo, Japan Full list of author information is available at the end of the article
}

31-km-long surface fault ruptures (Kumahara et al. 2016). Coseismic crustal deformation detected by InSAR (Geospatial Information Authority of Japan GSI 2016) and distribution of related seismicity (National Research Institute for Earth Science and Disaster Resilience NIED 2016) also indicate that the central to northeastern part of the FHFZ ruptured during the mainshock.

A large earthquake of $\mathrm{Mj} 6.5$ (Mw 6.2) also occurred at 21:26 (JST), April 14, 2016, about $28 \mathrm{~h}$ before the mainshock and is interpreted as the largest foreshock of the earthquake sequence (Fig. 1b) (JMA 2016a, b; GSI 2016; NIED 2016).

Based on field surveys, we found that surface ruptures appeared associated with the largest foreshock and enlarged after the mainshock at several sites along the 

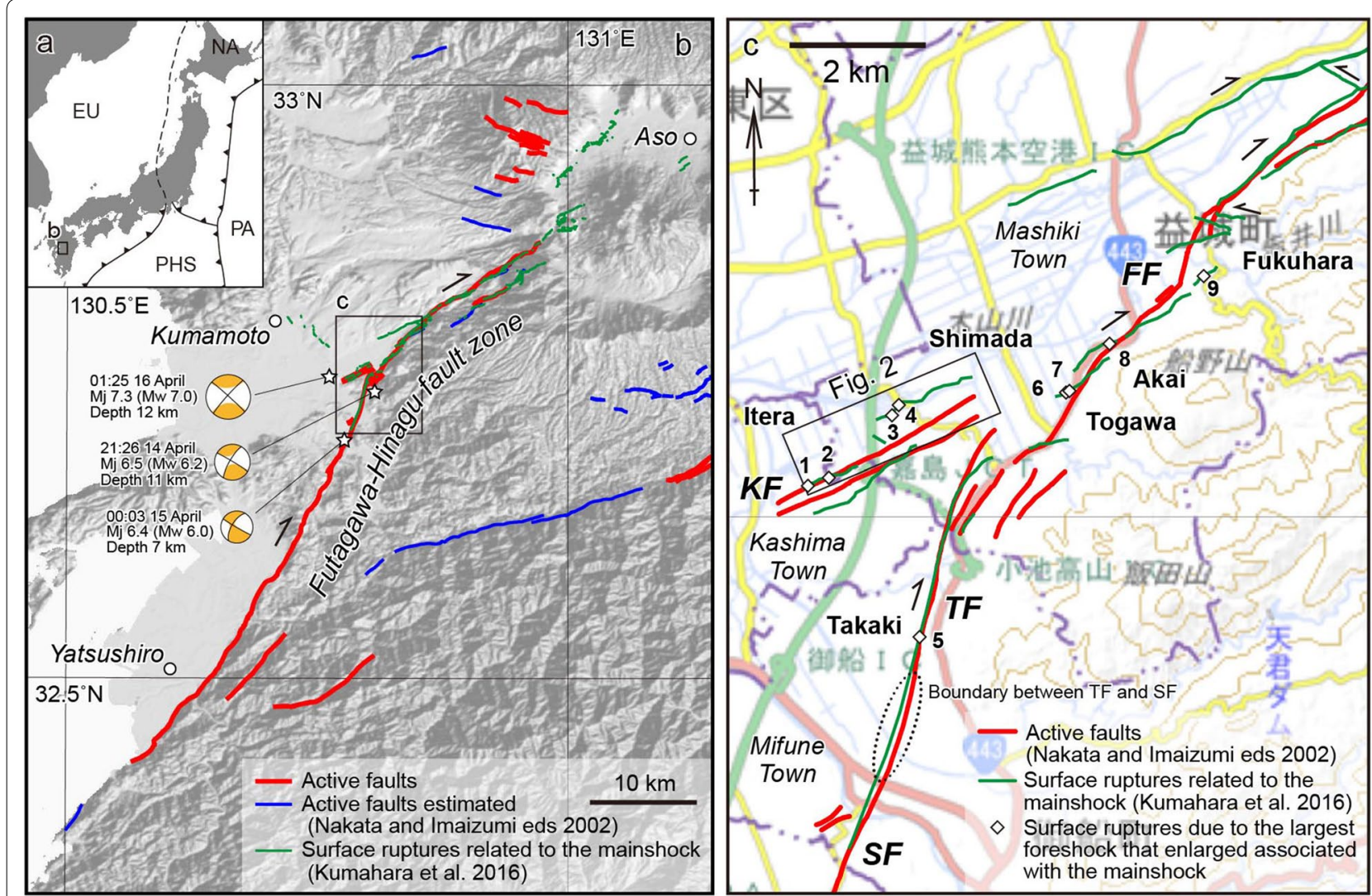

Fig. 1 a Plate tectonic setting of the Japanese islands, with triangles on the overriding plates. EU Eurasian plate, NA North American plate, PA Pacific plate, PHS Philippine Sea plate. b Active faults and surface ruptures related to the mainshock of the 2016 Kumamoto earthquake sequence around the FHFZ. Map is located in Fig. 1a. The 50-m-grid digital elevation model for shaded relief map is after the Fundamental Geospatial Data issued by the GSI. The epicenters and CMT solutions are after JMA (2016a). c Detailed map of active faults, surface ruptures related to the mainshock, and surface ruptures due to the largest foreshock that enlarged associated with the mainshock in the central part of the FHFZ. Map is located in Fig. 1b. The base map is the GSI maps. FF Futagawa fault, KF Kita-Amagi fault, TF Takano fault, SF Shirahata fault

southwestern part of the mainshock-derived rupture traces (Fig. 1c). This may be the first documentation worldwide of repeated surface faulting during the foreshock and mainshock. Our findings have important implications for understanding spatial relationship between the source faults of the largest foreshock and mainshock, or between fault geometries and rupture initiation points. In this paper, we describe the surface ruptures associated with the largest foreshock that became larger after the mainshock, and discuss their implications to the foreshock/mainshock process of the Kumamoto earthquake sequence.

Another large earthquake of $\mathrm{Mj}$ 6.4 (Mw 6.0) occurred at 00:03, April 15, 2016 (Fig. 1b) (JMA 2016a, b; GSI 2016; NIED 2016). However, we do not think that this earthquake produced surface ruptures along the FHFZ, because the epicenter of this earthquake was several kilometers southwest of the foreshock/mainshock-related ruptures and no surface rupture has been identified in the epicentral area of this earthquake.

\section{Methods}

The FHFZ extends northeast to north-northeast for more than $60 \mathrm{~km}$ (Fig. 1b) (Watanabe et al. 1979; RGAFJ 1991; Ikeda et al. 2001; Nakata et al. 2001; Nakata and Imaizumi 2002). The central part of the FHFZ (Fig. 1c) is composed of the Shirahata, Takano, Kita-Amagi, and Futagawa faults (RGAFJ 1991). The strike of the fault zone changes between the Takano fault and the Futagawa fault by $\sim 50^{\circ}$.

On the next day (April 15, 2016) following the occurrence of the largest foreshock, surface ruptures were identified by aerial observation from a helicopter and field surveys at several sites in Itera, Shimada, and Takaki (Fig. 1c). We revisited these sites after the mainshock and detected growth of the ruptures. In addition, local residents identified growth of the ruptures at several sites in Itera, Shimada, Togawa, Akai, and Fukuhara.

Geographical coordinates of the observation sites were obtained using handy GPS devices in the field, or read from Google Earth on 7 July 2016. Offset amounts were 
measured using tape measures and measuring rods in the field. We also interpreted high-resolution aerial photographs taken on 15 and April 16, 2016, by GSI (Fig. 2).

\section{Results}

We describe the surface ruptures at sites 1-9 (Figs. 1c, 2, $3,4,5)$.

At site $1\left(32^{\circ} 45^{\prime} 12.62^{\prime \prime} \mathrm{N}, 130^{\circ} 46^{\prime} 51.05^{\prime \prime} \mathrm{E}\right)$ in Itera, we identified mole-track structures and open cracks on 30 April, which extend ca. $\mathrm{N} 80^{\circ} \mathrm{W}$ across a farmland with framework of greenhouses (Fig. 4a). The landowner identified the ruptures after the largest foreshock, and they enlarged after the mainshock.

At site $2\left(32^{\circ} 45^{\prime} 16.55^{\prime \prime} \mathrm{N}, 130^{\circ} 47^{\prime} 2.40^{\prime \prime} \mathrm{E}\right)$ in Itera, we identified small cracks on an unpaved road on 15 April as shown in Fig. 3a (view toward the north). We revisited the site after the mainshock and found enlarged surface ruptures (Fig. 4b). We recognized ca. $10 \mathrm{~cm}$ of southside-down vertical offset between the northern and southern sides of the two fault traces, between which a small depression developed.

We identified numerous open cracks at site 3 $\left(32^{\circ} 45^{\prime} 40.43^{\prime \prime} \mathrm{N}, 130^{\circ} 47^{\prime} 30.56^{\prime \prime} \mathrm{E}\right.$, by Google Earth) in Shimada on 15 April. Based on local eyewitness accounts, the ruptures enlarged associated with the mainshock. At site $4\left(32^{\circ} 45^{\prime} 44.96^{\prime \prime} \mathrm{N}, 130^{\circ} 47^{\prime} 33.04^{\prime \prime} \mathrm{E}\right)$ in Shimada, we identified right-lateral offset of a paved road on 15 April as shown in Fig. 3b (view toward the south). There were three rupture traces, and the total dextral offset was several centimeters. On 30 April after the mainshock, five rupture traces were recognized and total right-lateral offset was measured at 13-14 cm (Fig. 4c, d).

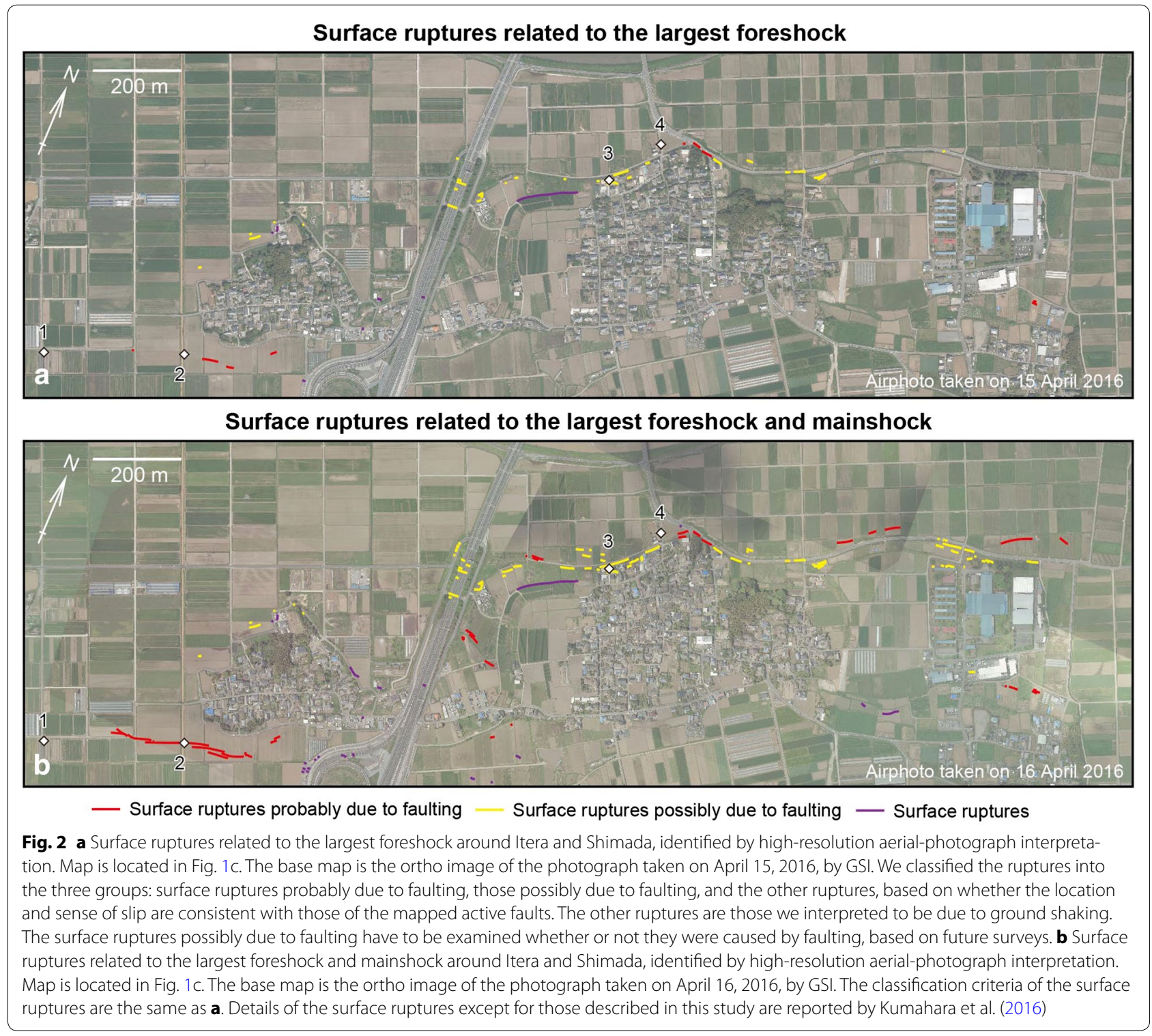




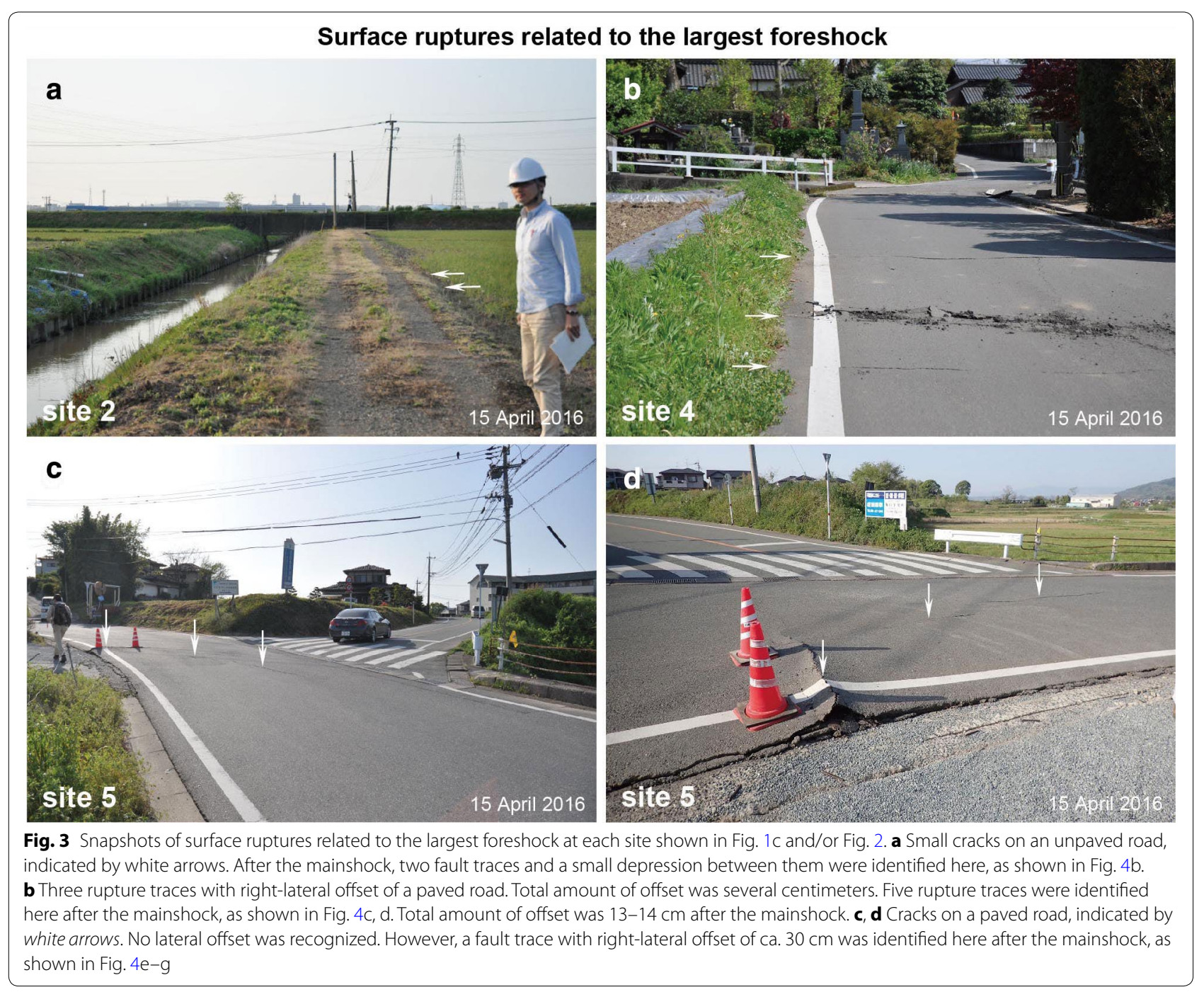

We visited site $5\left(32^{\circ} 44^{\prime} 18.25^{\prime \prime} \mathrm{N}, 130^{\circ} 47^{\prime} 45.12^{\prime \prime} \mathrm{E}\right)$ in Takaki on 15 April and found surface ruptures on a paved road as shown in Fig. 3c (view toward the west) and 3d (view toward the north). We also identified open cracks in the paddy field north of the road on the same day. However, no lateral offset was observed. We revisited the site after the mainshock and detected right-lateral offset of ca. $30 \mathrm{~cm}$ with no vertical offset on the road as shown in Fig. 4e (view toward the west), 4f (view toward the north), and $4 \mathrm{~g}$ (view toward the east). In the paddy field north of the road, right-lateral offset of ca. $50 \mathrm{~cm}$ with no vertical offset was identified. In other words, we confirmed in the field that the surface ruptures associated with the largest foreshock enlarged due to the mainshock at site 5 .

At site $6\left(32^{\circ} 45^{\prime} 49.80^{\prime \prime} \mathrm{N}, 130^{\circ} 48^{\prime} 52.52^{\prime \prime} \mathrm{E}\right)$ in Togawa, the concrete block under the walls of a house was ruptured (Fig. 4h). The width of the open crack was ca. $5 \mathrm{~cm}$ after the largest foreshock and was ca. $30 \mathrm{~cm}$ after the mainshock. At site $7\left(32^{\circ} 45^{\prime} 50.59^{\prime \prime} \mathrm{N}, 130^{\circ} 48^{\prime} 53.92^{\prime \prime} \mathrm{E}\right)$ in Togawa, we identified ca. $20 \mathrm{~cm}$ of right-lateral offset of a creek on 28 April (Fig. 5a). According to the local eyewitness accounts, almost half of the offset was due to the largest foreshock.

At site $8\left(32^{\circ} 46^{\prime} 10.70^{\prime \prime} \mathrm{N}, 130^{\circ} 49^{\prime} 14.69^{\prime \prime} \mathrm{E}\right)$ in Akai, an open crack appeared in association with the largest foreshock, which were later enlarged due to the mainshock (Fig. 5b), based on the local eyewitness accounts. At site $9\left(32^{\circ} 46^{\prime} 39.85^{\prime \prime} \mathrm{N}, 130^{\circ} 50^{\prime} 3.40^{\prime \prime} \mathrm{E}\right)$ in Fukuhara, the width of an open crack was ca. $2 \mathrm{~cm}$ after the largest foreshock and was ca. $5 \mathrm{~cm}$ after the mainshock (Fig. 5c) according to the house owner.

In addition to the sites described above, we identified surface ruptures related to the largest foreshock 


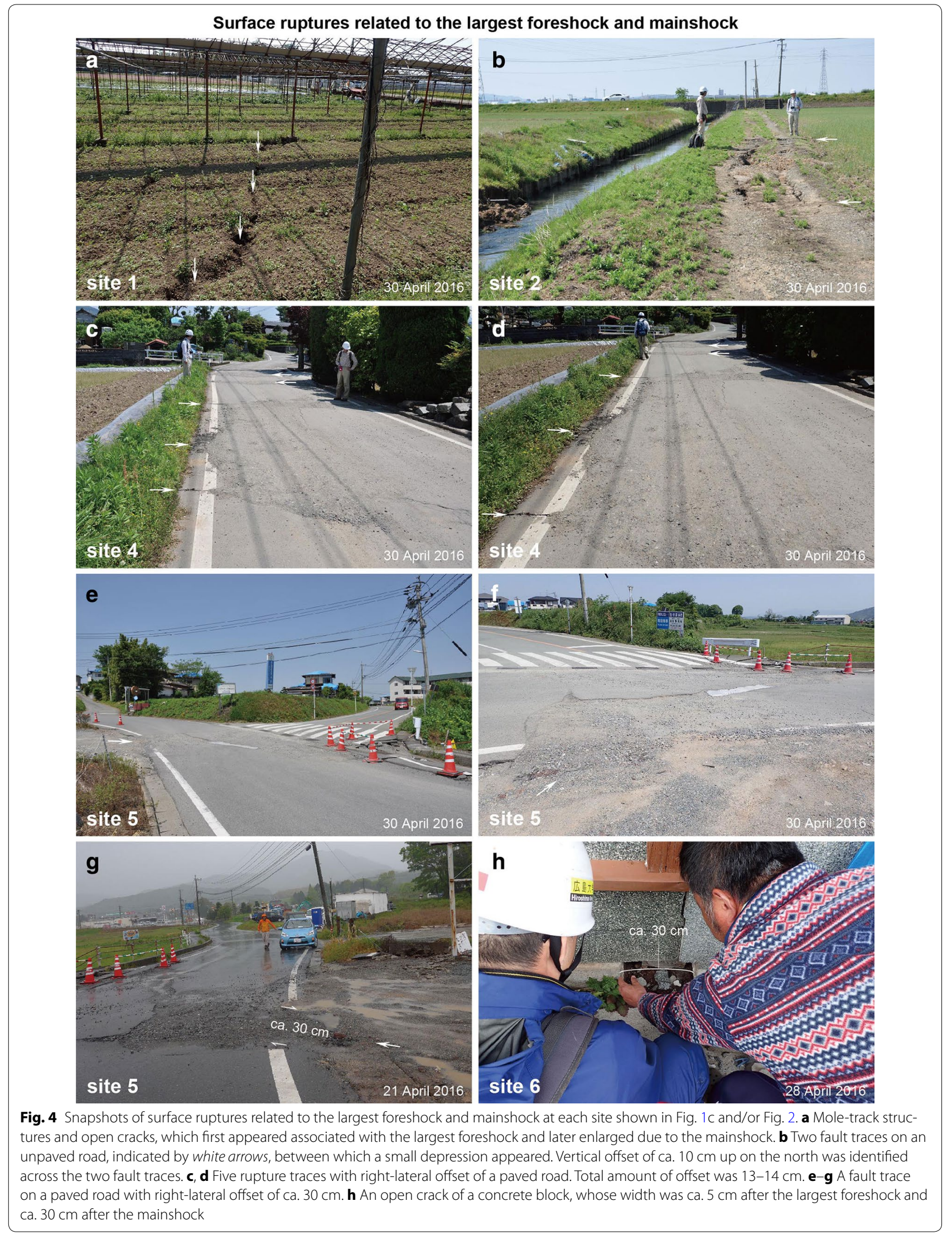




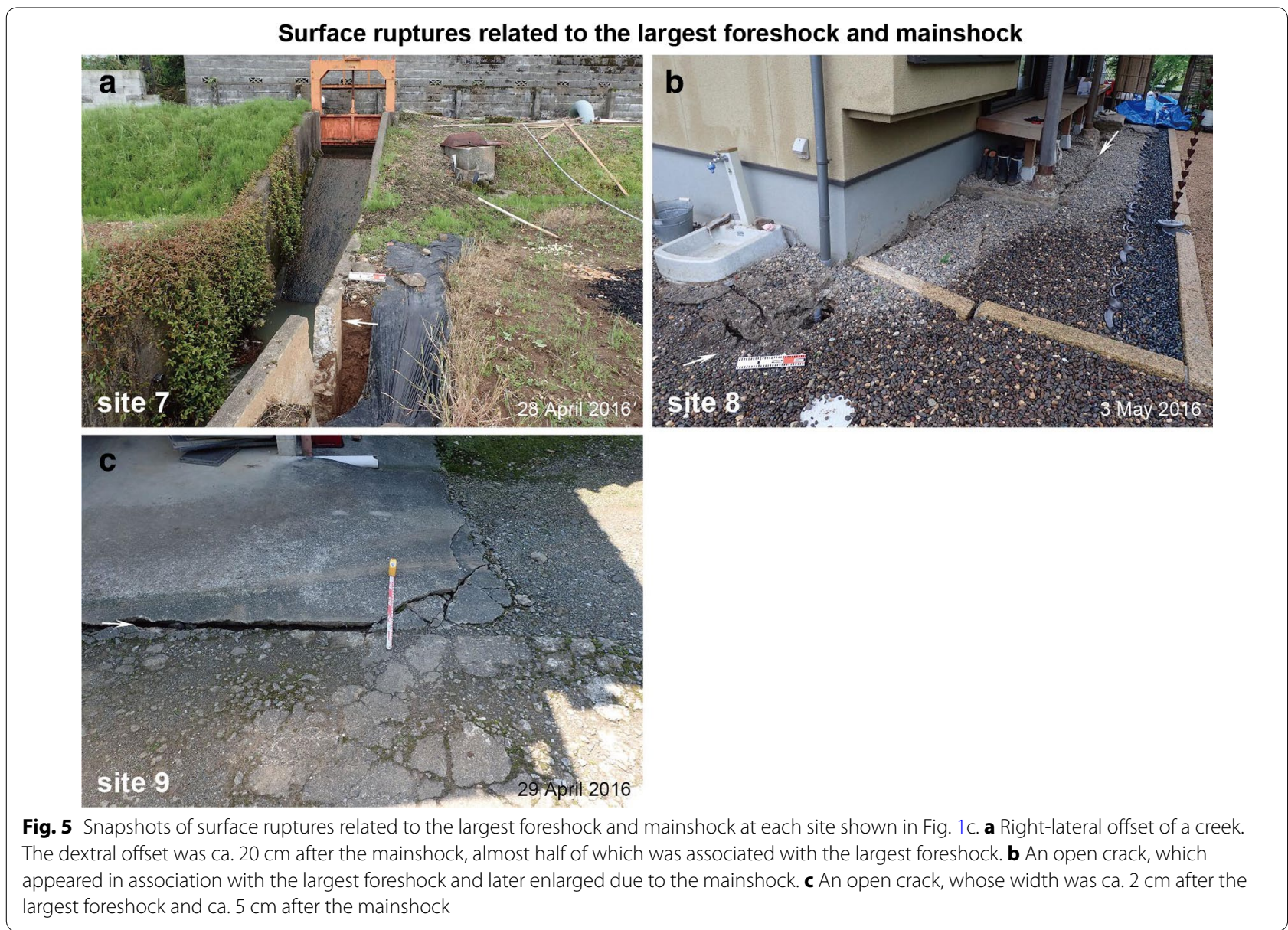

that enlarged due to the mainshock, by interpretation of high-resolution aerial photographs in Itera and Shimada (Fig. 2), although not all the ruptures were visible on the air photographs, such as those at site 1 .

\section{Discussion}

We were able to identify surface ruptures of the largest foreshock that enlarged associated with the mainshock at sites 1-9 in Itera, Shimada, Takaki, Togawa, Akai, and Fukuhara (Fig. 1c). These sites are located on the traces of the mainshock-derived surface ruptures along the KitaAmagi fault (sites 1-4), the Takano fault (site 5), and the southwestern end of the Futagawa fault (sites 6-9). The distance between the southernmost site (site 5) and easternmost site (site 9) is about $6 \mathrm{~km}$. Although we cannot exclude the possibility that these ruptures are due to triggered slip caused by strong ground motion, we suggest that the surface ruptures related to the largest foreshock are direct surface expression of slip on the seismogenic fault, because the magnitude of the earthquake was large enough to produce several-km-long surface fault ruptures, the epicenter of the largest foreshock was close enough to these ruptures, and the sense of slip was concordant with that of the mapped active faults.

Based on this study and Kumahara et al. (2016), we interpret that the Takano fault, the Kita-Amagi fault, and the southwesternmost part of the Futagawa fault moved during the largest foreshock event, and that the Shirahata, Takano, Kita-Amagi, and Futagawa faults moved during the mainshock. This is consistent with the coseismic crustal deformation imaged by InSAR (GSI 2016) and distribution of related seismicity (NIED 2016). This is one of the rare examples worldwide of repeated surface faulting during the foreshock and mainshock.

The epicenter of the mainshock is located near the source faults of the largest foreshock. This area corresponds to the most pronounced geometric bend (dePolo et al. 1989; McCalpin 2009) of the FHFZ. We propose that the largest foreshock was initiated due to stress concentration on the bend and then triggered the mainshock ca. $28 \mathrm{~h}$ after the largest foreshock. In other words, geometry of active faults would control the location of rupture initiation points as was proposed by King and Nábělek (1985), in addition to foreshock/mainshock processes. 
In order to examine the possibility of near-future large earthquakes on the southern part of the FHFZ, to which the 2016 Kumamoto earthquake sequence would have increased shear stress, we have to reveal the timing of the latest faulting event as well as recurrence intervals.

The Kita-Amagi fault seems to be branched toward the southwest from the main fault zone. This may indicate that the coseismic rupture of the northeastern part of the FHFZ terminates around the Kita-Amagi fault. However, the mainshock of the 2016 Kumamoto earthquake sequence started around the Kita-Amagi fault. Further investigations are needed to examine the relationship between fault branching and rupture propagation direction.

We considered the Futagawa, Kita-Amagi, Takano, and Shirahata faults as part of the continuous FHFZ, based on Watanabe et al. (1979), RGAFJ (1991), Ikeda et al. (2001), Nakata et al. (2001), and Nakata and Imaizumi (2002). On the other hand, Earthquake Research Committee, Headquarters for Earthquake Research Promotion (ERCHERP) (2016) regarded the Futagawa and Kita-Amagi faults as part of the Futagawa fault zone, and the Takano and Shirahata faults as part of the Hinagu fault zone. In addition, ERC-HERP (2016) interpreted that: (1) the largest foreshock ruptured the Takano-Shirahata segment of the Hinagu fault zone (which corresponds to the Takano and Shirahata faults); (2) the mainshock ruptured the Futagawa segment of the Futagawa fault zone (which corresponds to the Futagawa fault). This implies that the foreshock/mainshock sequence of the Kumamoto earthquake was successive events on the adjacent Futagawa and Hinagu fault zones. We do not think this interpretation is correct because the $6-\mathrm{km}$-long surface rupture of the largest foreshock is part of the $31-\mathrm{km}$-long surface rupture of the mainshock.

\section{Conclusions}

During the 2016 Kumamoto earthquake sequence, 6-km-long surface fault ruptures appeared in association with the largest foreshock of 14 April along the central part of the FHFZ. The same section ruptured again and increased the offset amount during the mainshock that produced the 31-km-long surface rupture along the central to northeastern part of the FHFZ. Surface faulting due to both the foreshock and mainshock is very rare worldwide, making the 2016 Kumamoto earthquake sequence a valuable example in active fault studies. The $6-\mathrm{km}$-long section corresponds to the largest geometric bend of the FHFZ. Stress concentration around the bend may have triggered the rupture of both the largest foreshock and mainshock that occurred ca. $28 \mathrm{~h}$ apart. The foreshock/ mainshock sequence may not be regarded as successive events on the adjacent Futagawa and Hinagu fault zones.

\section{Authors' contributions}

This work was planned by NS, HG, and YK. HG, YK, HT, and NS discussed and recognized the importance of the surface ruptures associated with the largest foreshock. Field surveys were conducted by all the authors. NS mapped surface ruptures using post-earthquake high-resolution air photographs. The manuscript was written by NS and HT, which was approved by the other authors. All authors read and approved the final manuscript.

\section{Author details}

${ }^{1}$ Faculty of Sustainability Studies, Hosei University, Tokyo, Japan. ${ }^{2}$ Graduate School of Letters, Hiroshima University, Higashi-Hiroshima, Japan. ${ }^{3}$ Graduate School of Education, Hiroshima University, Higashi-Hiroshima, Japan. ${ }^{4}$ Graduate School of Science, Kyoto University, Kyoto, Japan. ${ }^{5}$ Hiroshima University, Higashi-Hiroshima, Japan. ${ }^{6}$ Faculty of Education, Yamaguchi University, Yamaguchi, Japan. ${ }^{7}$ Graduate School of Education, Okayama University, Okayama, Japan. ${ }^{8}$ Yame High School, Chikugo, Japan.

\section{Acknowledgements}

We thank local people for their cooperation during our field surveys. We also thank the Asahi Shimbun Company for giving NS the opportunity of the helicopter flight, as well as the GSI for providing NS with post-earthquake high-resolution aerial photographs. The editor and two anonymous reviewers provided constructive comments that greatly improved the manuscript. This work was supported by JSPS KAKENHI Grant Numbers JP15K16285 and JP16H06298, and MEXT of Japan, under its Earthquake and Volcano Hazards Observation and Research Program.

\section{Competing interests}

The authors declare that they have no competing interests.

Received: 30 July 2016 Accepted: 13 October 2016

Published online: 03 November 2016

\section{References}

de Polo CM, Clark DG, Slemmons DB, Aymand WH (1989) Historical basin and range province surface faulting and fault segmentation. In: Schwartz DP, Sibson RH (eds) Fault segmentation and controls of rupture initiation and termination, vol 89-315. U.S. Geological Survey Open File Report, Denver, pp 131-162

Earthquake Research Committee, Headquarters for Earthquake Research Promotion (2016) Evaluation of the 2016 Kumamoto earthquake sequence (Version of 13 May 2016). http://www.jishin.go.jp/main/index-e.html. Accessed 7 July 2016

Geospatial Information Authority of Japan (2016) Detection of crustal movement by ALOS-2 InSAR. http://www.gsi.go.jp/BOUSAI/H27-kumamotoearthquake-index.html\#3. Accessed 7 July 2016 (in Japanese)

Ikeda Y, Chida N, Nakata T, Kaneda H, Tajikara M, Takazawa S (2001) 1:25,000scale active fault map in urban area "Kumamoto". Technical Report of the Geographical Survey Institute, Ibaraki, D1-No.388 (in Japanese)

Japan Meteorological Agency (2016a) CMT solutions of the earthquake occurred in April 2016. http://www.data.jma.go.jp/svd/eqev/data/mech/ cmt/cmt201604.html. Accessed 7 July 2016 (in Japanese)

Japan Meteorological Agency (2016b) The 2016 Kumamoto earthquake sequence (Part 7). http://www.jma.go.jp/jma/press/1604/16a/kaisetsu201604160330.pdf. Accessed 7 July 2016 (in Japanese)

King G, Nábělek J (1985) Role of fault bends in the initiation and termination of earthquake rupture. Science 228:984-987

Kumahara Y, Goto H, Nakata T, Ishiguro S, Ishimura D, Ishiyama T, Okada S, Kagohara K, Kashihara S, Kaneda H, Sugito N, Suzuki Y, Takenami D, Tanaka K, Tanaka T, Tsutsumi H, Toda S, Hirouchi D, Matsuta N, Moriki H, Yoshida H, Watanabe M (2016) Distribution of surface rupture associated with the 2016 Kumamoto earthquake and its significance. Japan Geoscience Union Meeting 2016, MIS34-05

McCalpin JP (ed) (2009) Paleoseismology, 2nd edn. Academic Press, San Diego

Nakata T, Imaizumi T (eds) (2002) Digital active fault map of Japan. University of Tokyo Press, Tokyo (in Japanese)

Nakata T, Okada A, Chida N, Kaneda H, Tajikara M, Takazawa S (2001) 1:25,000 scale active fault map in urban area "Yatsushiro". Technical Report of the Geographical Survey Institute, Ibaraki, D1-No.388 (in Japanese) 
National Research Institute for Earth Science and Disaster Resilience (2016)

Epicenter distribution of seismicity related to the earthquake of the

Kumamoto region, Kumamoto Prefecture on 16 April 2016. http://www.

hinet.bosai.go.jp/topics/nw-kumamoto 160416/. Accessed 7 July 2016 (in Japanese)

Research Group for Active Faults of Japan (1991) Active faults in Japan: Sheet maps and inventories, revised edn. University of Tokyo Press, Tokyo (in Japanese with English abstract)
Watanabe K, Momikura K, Tsuruta K (1979) Active faults and parasitic eruption centers on the west flank of Aso caldera, Japan. The Quaternary Research 18:89-101 (in Japanese with English abstract)

\section{Submit your manuscript to a SpringerOpen ${ }^{\circ}$ journal and benefit from:}

- Convenient online submission

- Rigorous peer review

- Immediate publication on acceptance

- Open access: articles freely available online

- High visibility within the field

- Retaining the copyright to your article 